\title{
ROLE OF EMPLOYEE ENGAGEMENT ON WORK SATISFACTION REGARDING EMPLOYEE SERVICES QUALITY AT THE GRAND SANTHI HOTEL DENPASAR
}

\author{
*Ni Made Dwi Puspitawati ${ }^{1}$, Adhi Krisna Yuliawan², \\ Universitas Mahasaraswati Denpasar, Bali, Indonesia
}

\begin{abstract}
The hotel is one of the facilities that strongly supports the progress of the tourism sector. Problems most commonly occur in regards to the lack of service quality are due to complaints received and employees who do not understand their functions and tasks clearly. Job satisfaction could be related to this lack of service that in turn affects the level of company engagement. The study examines the role of employee engagement on the relationship between work satisfaction and service quality. Results using path analysis show that work satisfaction influences employee engagement and service quality; and employee engagement influences service quality. Thus, proving that a high level of satisfaction will result in a higher sense of employee attachment to companies, which will create quality services.
\end{abstract}

Keywords: work satisfaction, employee engagement, service quality

\section{A. Introduction}

At present, companies must be able to survive and overcome all challenges and threats to achieve its goals. Human resources are the capital of companies that must get more attention because their roles and functions are irreplaceable by other resources. The survival of the company depends on the loyalty of human resources. If a company wishes to achieve good performance, then it is reflected in the quality of services provided, as is especially true in service companies. Wirawan (2009) states that quality is the completeness of results that might be achieved in the end. Timely delivery, completeness of equipment,

\footnotetext{
*Corresponding Author.

e-mail: dwipuspitawati10@unmas.ac.id
} 
courtesy, comfort, affordability in terms of price, and accuracy alongside responsiveness are measurement forms of service quality (Wibowo, 2012). Employees' satisfaction in their work and their commitment to the organization affects quality of services (Malhotra \& Mukherjee, 2004).

Job satisfaction raises a sense of pleasure towards the work from the perspective of the employees. While the satisfaction of employees at work will increase the level of productivity, the continuous improvement of attitudes in providing excellent services from the perspective of the company (Suwatno \& Priansa, 2011). According to Handoko (2011), job satisfaction is a feeling or emotional attitude of an individual, expressed through a feeling of pleasure or displeasure in their work. Organizational performance will increase if job satisfaction continues to be maintained (Akbar et al., 2016). Hella (2011) and Sukotjo (2011) similarly state that the satisfaction of employees when working affects the services provided which will simultaneously impact on customer satisfaction.

Employee engagement cannot be separated from the employees' level of satisfaction, which will affect the organization (Widjaja \& Devie, 2014). Mujiasih and Ika (2012) assert that an organization should stay focus on improving employee engagement because it will affect productivity and customer satisfaction. Employee loyalty will be formed by always paying attention to employee engagement (Ramadhan \& Sembiring, 2014). Engaged employees will increase their commitment to the company's goals, complete the task with all their abilities, behave well while working, and they will ensure that the task has been carried out properly in accordance with the objectives and ready for improvement or evaluation if needed (Marciano, 2010). According Osney Media Ltd survey, employee engagement was a top priority experienced by approximately $82 \%$ of respondents. Employee engagement is basically in accordance with a person's commitment and satisfaction to his work, or it can be said that employee engagement is a form of job satisfaction in a modern context (Schmidt et al., 1993). Hence, employee engagement will have an impact on improving employee performance, which is one of the successes of a company (Siddhanta \& Roy, 2010).

The hotel is one of the accommodations that strongly supports the progress of the tourism sector. A hotel provides facilities and services such as rooms, 
Ni Made Dwi Puspitawati, Adhi Krisna Yuliawan / Role of Employee Engagement on Work Satisfaction Regarding Employee Services Quality at the Grand Santhi Hotel Denpasar

conference rooms to restaurants and bars. Information on hotel services is usually provided regarding registration, accommodation facilities, restaurants, as well as seminar, meetings and other activities related to the facilities of the hotel. Hotels sell services in matters relating to the hospitality and skills of hotel employees in providing the best service to their customers (Chen, 2007). The Grand Santhi Hotel is an individually owned hotel located in two locations, on the north side and the south side of Patih Jelantik road, Denpasar. The building in the North was established in 1974 in the form of a small inn known as Hotel Marga Ayu. This building was renovated in 2000 into a multi-storey building. The hotel at the south side of the Patih Jelantik road is formerly known as Hotel Kencana, consisting of 12 rooms and the hotel was renovated in 2006 and was reopened in 2007. Both buildings are currently called the Grand Santhi Hotel. The hotel is intended for business people from all over Indonesia who would come to Bali to develop their business. With additional meeting room facilities owned, the Grand Santhi Hotel has developed the market on the sales of meeting packages.

The problem that often occurs in Grand Santhi Hotel is the problem of consumer complaints, which sometimes forces employees to exercise more selfcontrol. Employees are required to be able to provide optimal service so that consumer complaints do not become more and more protracted because it will greatly affect the survival of the company. From this phenomenon, the researcher assumes that in order to continue to maintain service quality in order to survive in the competition of the tourism industry, the company must be able to provide satisfaction to employees. If the employee feels satisfied, the emotional feeling of the employee will be attached to the company, then the employee will increasingly strive to serve wholeheartedly to achieve the company's ideals.

The study is aimed at examining the role of employee engagement on the influence of job satisfaction on service quality. Respondents of the study are employees who deal directly with consumers at the Grand Santhi Hotel.

\section{B. Literature Review}

Suwanto and Priansa (2011) assert that individual attitudes in various aspects at work is one of the ways the employees can determine the amount of 
work produced. Job satisfaction is how the job is perceived as pleasant or unpleasant by the employees (Umar, 2010). Sopiah (2008) contends that job satisfaction is caused by the following work aspects: promotion, compensation, workload, superior, co-workers, work safety, work conditions, company policy, communication quality with superiors and co-workers, responsibilities charged, recognition of work results, achievements, and opportunities for self-development. According to Robbins (2006), employees at work also require interaction with colleagues and superior, adherence to organizational rules and policies, meeting performance standards, and adaptability to a work environment that is often less than ideal. The results of evaluating one's work experience will lead to a positive emotional state that can be called job satisfaction (Mathis \& Jackson, 2011).

Furthermore, the emotional state of employees due to the fulfillment of reward for the job done as opposed to the expected return for the work done is an understanding of job satisfaction (Martoyo, 2007). According to Sun et al. (2016), to measure employee job satisfaction several factors can be used such as assessment of work, salary, profit, future career development, and the overall work environment. Thus, work satisfaction is a positive feeling of an employee who feels satisfied with the workload, compensation, supervisors, co-workers, and work environment.

Employee engagement is an emotional attachment to the work and the organization that gives rise to the employees' best motivation and ability to achieve success and to attain a set of benefits that can be enjoyed by the organization and its individuals (McLeod, 2009). According to Ramadhan and Sembering (2014), employee engagement raises employee loyalty and reduces their desire to leave the company voluntarily.

Schaufeli and Bakker (2003) propose three elements of employee engagement. These are described as follows:

1. Vigor is physical and mental strength at work that is characterized by optimal energy, courage and strength to strive, the drive, the ability, and the willingness to earnestly complete the work to get maximum results, and to persevere, to persist, to be relentless, and to be excited when difficulties come. 
Ni Made Dwi Puspitawati, Adhi Krisna Yuliawan / Role of Employee Engagement on Work Satisfaction Regarding Employee Services Quality at the Grand Santhi Hotel Denpasar

2. Dedication is the enthusiasm shown by employees at work, the pride in their work, the ingenuity of ideas or inspiration, and to remain diligent even in the face of challenges. Employees with high dedication values usually consider the experience valuable. In addition, they will always feel enthusiastic about their work and feel proud of the organization. Conversely, employees with low dedication values will find work as meaningless, uninspiring, or non-challenging experience, and such employees have no enthusiasm for their work or pride in the organization.

3. Absorption is a sense of employee attachment through the dedication of their full attention to the work at hand where they are always happy, focused, and serious. They assume that time passes faster when they are working so that it is sometimes difficult to break away from work.

Thus, employee engagement is a sense of attachment that exists in individuals to give the best effort with courage, dedication, and full attention to the work as an effort to achieve organizational goals.

Schuler and Jackson (1997) state that quality is a consistent and continuous delivery of product and service that is always given in accordance with the quality dimension. Quality is a performance element for measuring work, similar to the criteria for teaching, research, and service to assess the quality of a college lecturer (Mathis \& Jackson, 2011). According to Puspitawati and Riana (2014), quality is the whole product: both goods and services, in terms of appearance and characteristics offered but is able to create more value than what was expected. The following five dimensions are used in measuring service quality according to (Parasuraman, 2003; Schuler \& Jackson, 1997):

1. Direct evidence is everything that has form such as facilities, equipment, employees, and communication tools.

2. Reliability is promptness of service and the strive for satisfaction.

3. Responsiveness is the willingness to help customers and to serve with initiative.

4. Guarantee is the courtesy, the ability to serve, the trustworthiness of employees in giving information, and the avoidance of unwanted risks.

5. Empathy is the feeling of caring in facilitating communication and in always understanding the needs of customers. 
In accordance with the aforementioned theories, the quality of service is a level of service execution that can be assessed from the appearance and characteristics of the product or service. Figure 1 depicts the model to be tested in the current study.

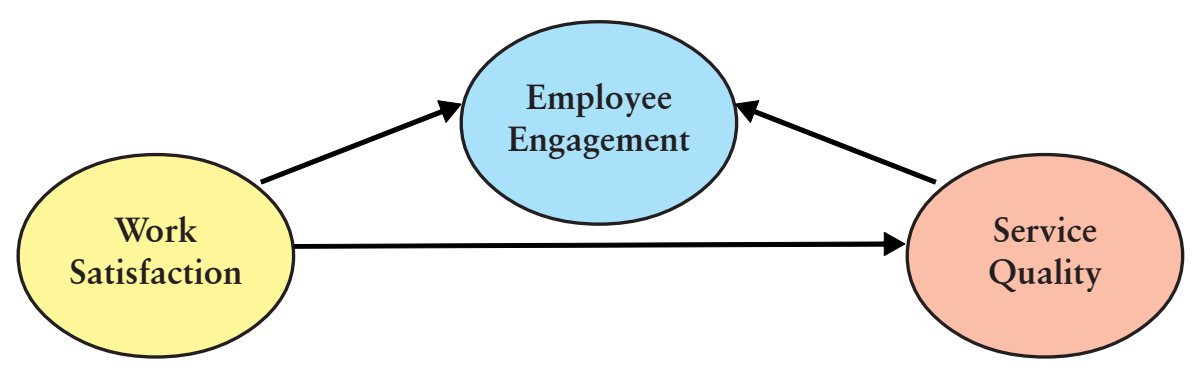

Figure 1 Research Model

\section{Research Method}

The sample of this study is employees who were dealing directly with consumers in Grand Santhi Hotel. The object of the study includes job satisfaction, employee engagement, and service quality. The following are the definitions of the variables of the research:

1. Job Satisfaction $(\mathrm{X})$ is a positive feeling of an individual who is satisfied with the workload, compensation, supervisor, co-workers, and the work environment.

2. Employee Engagement $\left(\mathrm{Y}_{1}\right)$ is a sense of attachment that exists in every individual to give effort with courage, dedication and focus to his work in an effort to achieve organizational goals.

3. Service Quality $\left(\mathrm{Y}_{2}\right)$ is a level of service quality that can be assessed from the appearance and characteristics of the product / service.

There are 39 employees of the Grand Santhi Hotel, who are dealing directly with consumers. This study uses cross sectional survey - data collection techniques where information collection is carried out at certain times (Kountur, 2003) through: (a) interviews on hotel employees, and (b) questionnaires using a Likert scale that were given to employees of the Grand Santhi Hotel. 
Test instrument validation is done using the confirmatory factor analysis. Hair et al. (2006) state that the rule of thumb in this study is that the loading factors must be more than 0.040. The Cronbach's Coefficient Alpha is used to test the reliability of data. The better the reliability of the Cronbach value's Coefficient Alpha, the closer its value to 1.0.

\section{Result and Discussion}

The descriptive data show the following. The proportion between male and female respondents is balanced; male is 51.3 percent and female is 48.7 percent. Respondents were aged mostly at 31-40 years, amounting to 59.0 percent. Most respondents had high school education, which is 53.8 percent. Most respondents have a working period of 6 to 10 years, which is 53.8 percent. The results of the instrument validity test show that all statement items are suitable to be used for all targets. Reliability testing shows a Cronbach alpha number of more than 0.06, which means the questionnaire has passed the test and can be used to receive input from the respondents.

\section{Path Analysis Model Test}

This test shows the direct or indirect influence of the variables hypothesized by examining the pattern of relationships between variables in the study.

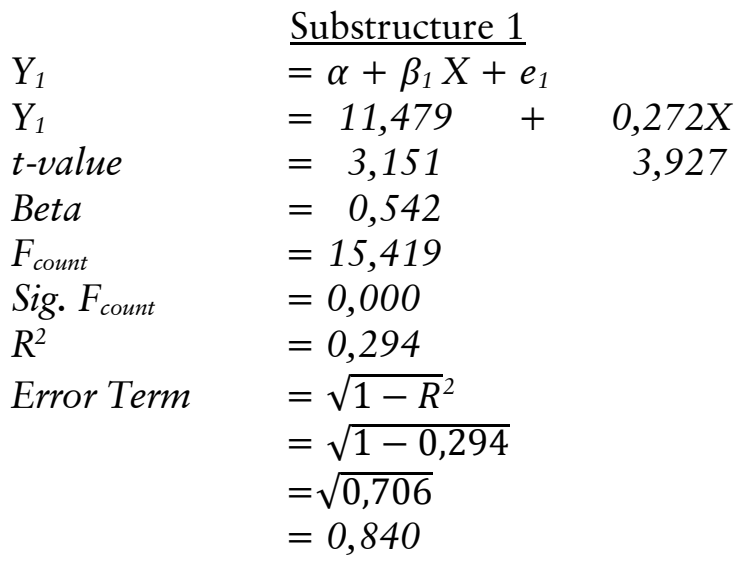




$$
\begin{aligned}
& \text { Substructure } 2 \\
& Y_{2} \quad=\alpha+\beta_{2} X+\beta_{3} Y_{1}+e_{2} \\
& \text { Std error }=-3265+0,236 X+1,060 Y_{1} \\
& \begin{array}{llll}
T_{\text {count }} & =-1,352 & 4,848 & 10,949
\end{array}
\end{aligned}
$$

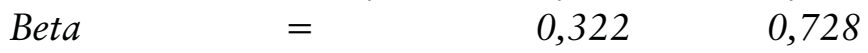

$$
\begin{aligned}
& F_{\text {count }} \quad=142,359 \\
& \text { Sig. } F_{\text {count }} \quad=0,000 \\
& R^{2} \quad=0,888 \\
& \text { Error Term }\left(e_{2}\right)=\sqrt{1-R^{2}} \\
& =\sqrt{1-0,888} \\
& =\sqrt{0,112} \\
& =0,335
\end{aligned}
$$

Job satisfaction directly affects employee engagement, which is characterized by the acquisition of ñ1 of 0.542. Likewise, the direct effect of job satisfaction on service quality is evidenced by the acquisition of $\rho 2$ value of 0.322 . Furthermore, the influence of employee engagement directly on service quality is $\rho 3=0.728$. The role of employee engagement as a mediating variable on the influence of job satisfaction on service quality can be obtained by the formula, namely $(\rho 1 \times \rho 2)=(0.542 \times 0.728)=0.395$.

$$
\begin{aligned}
\text { Total influence } & \left.=\rho_{2+(} \rho_{1 \times} \rho_{3}\right) \\
& =0,322+(0,542 \times 0,728) \\
& =0,322+0,395 \\
& =0,717
\end{aligned}
$$

The total effect of the variable job satisfaction $(\mathrm{X})$ on employee engagement (Y1) and service quality (Y2) variables of Grand Santhi Hotel employees was obtained at 0.717 or 71.7 percent. In this step, the validity of the model is examined by the results of the total determination coefficient

$$
\begin{aligned}
R^{2} m & =1-\left(e_{1}^{2} x e_{2}^{2}\right) \\
& =1-(0,840)^{2}(0,335)^{2} \\
& =0,921
\end{aligned}
$$

The calculation above shows the diversity of data obtained is 92.1 percent or the information contained is 92.1 percent, which is shown by the model, while the remaining 7.9 percent is the variable that is likely to be proven in the next research. 
Ni Made Dwi Puspitawati, Adhi Krisna Yuliawan / Role of Employee Engagement on Work Satisfaction Regarding Employee Services Quality at the Grand Santhi Hotel Denpasar

\section{Theory Trimming}

Theory Trimming is done with the intention to get a model with empirical data. Validation test is indicated by the level of significant $=0.05$. The values (sig.) obtained are as follows: (a) Sub-structure 1 is stated as job satisfaction valued at 0.000 or less than 0.05 , (b) Substructure 2 is job satisfaction of 0.000 and employee engagement is 0.000 or in other words, both showed value of less than 0.005 . In accordance with these results, the model path can be concluded as valid. Figure 2 presents the summary of results.

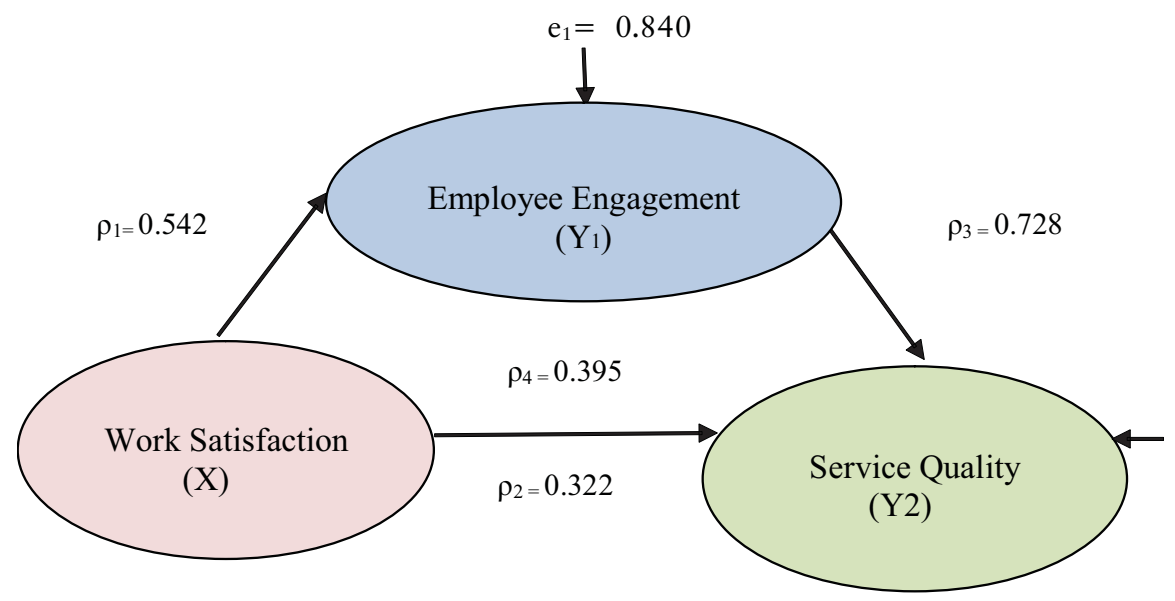

Figure 2 Model Validation

The next step is to interpret the analysis of the results as well as the hypotheses that have been tested in this study.

Table 1 Summary of Results

\begin{tabular}{|l|c|c|c|}
\hline \multicolumn{1}{|c|}{ Contribution } & Path Coefficient & t(count) & (Sig.) Description \\
\hline $\begin{array}{l}\text { Job Satisfaction }(\mathrm{X}) \text { against } \\
\text { Employee Engagement }\left(\mathrm{Y}_{1}\right)\end{array}$ & 0.542 & 3.927 & 0.000 Significant \\
\hline $\begin{array}{l}\text { Job Satisfaction }(\mathrm{X}) \text { against } \\
\text { Service Quality }\left(\mathrm{Y}_{2}\right)\end{array}$ & 0.322 & 4.848 & 0.000 Significant \\
\hline $\begin{array}{l}\text { Employee Engagement }\left(\mathrm{Y}_{1}\right) \\
\text { against Service Quality }\left(\mathrm{Y}_{2}\right)\end{array}$ & 0.728 & 10.949 & 0.000 Significant \\
\hline
\end{tabular}

In Table 1, Job satisfaction affects employee engagement $(t=3.927 ; p=$ 0.000). This means the effect of job satisfaction on employee engagement is 
proven to be significantly positive. So that it can mean that if employees feel job satisfaction they will feel more attached to the company. Job satisfaction positively affects service quality $(t=4.848 ; p=0.000)$. The purpose of the statement is that if the employee is satisfied it will improve the quality of the services provided. Employee engagement affects service quality $(t=10.949$; $\mathrm{p}=0.000$ ). It can be interpreted that the effect of employee engagement on service quality is positive and significant. Which means that if employees have an interest in the company, they are increasingly providing quality services.

\section{Employee engagement is influenced by job satisfaction}

Job satisfaction is stated to have a significant positive influence on employee engagement. Meaning that if employees feel satisfied with the work, the higher the level of engagement of the employee to the company and vice versa. Lower level of employee satisfaction reduces the sense of attachment to the company.

An indicator to measure employees satisfaction is by how well managed they are by the company so that it contributes to employee engagement. This is in accordance with the employee's assessment, where the employer gives fair treatment to each employee by listening to every suggestion, giving priority to common interests, and by paying attention to the same career opportunities for each employee so that they feel satisfied. Besides that, the issue of salary will increase the attachment to the company.

This research is relevant to Kari (2013) who states that there was a positive influence on employee's job satisfaction management, which could mean that if the level of job satisfaction were high then it would be in line with the level of engagement of Bandung State Polytechnic staff. In the research of Humairoh and Wardoyo (2017) assert that leaders should know how high employee job satisfaction because when employees reach the highest satisfaction, there will be an attachment between the employees with the organization.

\section{Effect of job satisfaction on service quality}

Job satisfaction significantly and positively affects service quality, which means that employee satisfaction will reflect the level of service quality. In accordance with the results of employee appraisal, readiness to serve consumers, reliability in providing clear information to consumers, and employee physical 
Ni Made Dwi Puspitawati, Adhi Krisna Yuliawan / Role of Employee Engagement on Work Satisfaction Regarding Employee Services Quality at the Grand Santhi Hotel Denpasar

appearance will be able to increase customer satisfaction. In addition, employees will provide quality services if employees are satisfied with their work.

The findings here are in line with another research that states that the quality of shop employee services in Hong Kong is significantly influenced by employee satisfaction (Yee et al., 2008). Job satisfaction is the center of attention in the service industry, because it will have an impact on the delivery of service quality, because service companies must continue to prioritize quality services with the support of employees who are always loyal to the company through employee job satisfaction (Munhurrun et al., 2010). This statement is similar to what was stated by Halim (2015), where drivers will serve the customer wholeheartedly when they feel job satisfaction especially with colleagues. The higher the level of job satisfaction of PT Solo Central Taxi employees, the better the quality of service (Wuryandradi, 2014).

\section{Effect of employee engagement on service quality}

Employee engagement shows a significant positive influence on service quality, it shows that if employees have a close engagement with the company, the more the employee gives the best quality of service, but on the contrary, if the employee's attachment is low towards the company, the lower the quality of the service provided. The evaluation results from the employee explained the happiness experienced in work, as the feeling of being happy with the work and the enthusiasm in working would be able to improve service quality so does to create customer satisfaction.

Wyatt and Wah's (2001) research is relevant to these results, where as individuals, an employee wants to be respected in their work environment. Service quality can be produced if employees are able to be treated like adults. Employee engagement is an important aspect in terms of increasing productivity, probability, and consumer loyalty (Kreitner \& Kinicki, 2014).

The role of employee engagement on the influence of job satisfaction on service quality

The role of employee engagement on job satisfaction that affects service quality is stated as significant and positive, which shows that if employees are 
satisfied, it will increase the employee's engagement with the company and they will be ready to provide quality services.

Whether or not individuals can be satisfied can be measured through workload indicators, promotions, salary colleagues, and supervisors. These have contributed to the happiness and contentedness of employees in every job and with sincerity to provide good quality service so that customer satisfaction can be attained.

\section{F. Conclusion}

This study examines the role of employee engagement in mediating the relationship between wok satisfaction and service quality of employees a Grand Santhi Hotel. Results of analysis lead to the following conclusions. Job satisfaction affects employee engagement meaning that if an employee is satisfied with the amount of workload and salary. Service quality is influenced by job satisfaction in which it shows that in providing services to consumers. Employee engagement affects service quality, which means that if employees feel an emotional attachment to the company. They will show performance according to the company's expectations by always giving the best quality of service.

\section{G. References}

Akbar, F.H., Hamid, D., \& Djudi, M. 2016. Pengaruh Kepuasan Kerja terhadap Komitmen Organisasional dan Kinerja Karyawan (Study pada Karyawan Tetap PG Kebon Agung Malang). Jurnal Administrasi Bisnis, Vol. 38, No. 2, pp. $79-88$.

Azeem, S.M. 2010. Job Satisfaction and Organizational Commitment among Employees in the Sultanate of Oman. Journal of Psychology, Vol. 1, No. 4, pp. 295-299.

Chen, Cheng-nan. 2007. The Relation among Social Capital, Entrepreneurial Orientation, Organizational Resources and Entrepreneurial Performance for New Ventures. Contemporary Management Research, National Cheng Kung University.

Hair, J.F., Anderson, R.E., Tatham, R.L. \& Black W.C. 1995. Multivariate Data Analysis (Forth ed.). New Jersey: Prentice-Hall. 
Ni Made Dwi Puspitawati, Adhi Krisna Yuliawan / Role of Employee Engagement on Work Satisfaction Regarding Employee Services Quality at the Grand Santhi Hotel Denpasar

Halim, I.A. 2015. Pengaruh Kepuasan Kerja dan Disiplin Kerja pada Kualitas Layanan Sopir di PT Usaha Jaya Gresik. AGORA, Vol. 1, No. 2, pp. 210216.

Handoko, Hani T. 2011. Manajemen Sumber Daya Manusia. Yogyakarta: BPFE Yogyakarta.

Hella, M.A. 2011. Pengaruh Motivasi terhadap Kepuasan Kerja dan Kualitas Pelayanan Karyawan PT. PLN (Persero) Distribusi Bali. Tesis. Program Pascasarjana Universitas Indonesia.

Humairoh \& Wardoyo. 2017. Analisis Pengaruh Budaya Organisasi terhadap Employee Engagement dengan Kepuasan Kerja sebagai Variabel Intervening (Studi Kasus: Perusahaan Jasa Layanan Pelabuhan). Ultima Management, Vo. 9, No. 1, pp: 1-27.

Judge, T.A., Thoresen C.J., Bono, J.E., \& Patton, G.K. 2001. The Job Satisfaction - Job Performance Relationship: A Qualitative and Quantitative Review. Psychological Bulletin, Vo. 127, No. 3, pp. 376-407.

Kari, Andi. 2013. Pengaruh Kepuasan Kerja dan Motivasi Kerja Terhadap Engagement Pegawai Tenaga Kependidikan di Politeknik Negeri Bandung. Tesis. Universitas Pendidikan Indonesia, Bandung.

Kreitner, R. \& Kinicki, A. 2014. Perilaku Organisasi. Jakarta: Salemba Empat. Kountur, R. 2003. Metode Penelitian. PPM Jakarta.

Malhotra, N \& Mukherjee, A. 2004. The Relative Influence of Organizational Commitment and Job Satisfaction on Service Quality of Customer Contact Employees in Banking Call Centers. Journal of Service Marketing, Vol. 18, No. 3, pp. 162-174.

Marciano. 2010. Culture of Employee Engagement with the Principle of RESPEC.

New York: Mc. Graw-Hill.

Martoyo, S. 2007. Manajemen Sumber Daya Manusia. Yogyakarta: BPFE.

Mathis, R.L. \& Jackson. 2011. Human Resource Management. Jakarta: Salemba Empat.

Mc. Leod, Jr., \& Raymond S. 2009. Sistem Informasi Manajemen Edisi 10. Jakarta: Salemba Empat.

Mujiasih, E. \& Ika, Z.R. 2012. Meningkatkan Work Engagement Melalui Gaya Kepemimpinan Transformasional dan Budaya Organisasi. Journal Psikologi Undip, pp. 1-20. 
Munhurrun, P.T., Naido, P. \& Bhiwajee, S.D.L. 2010. Measuring Service Quality Perceptions of Employees. Journal of Business Research, Vol. 4, No. 1, pp. 47-58.

Parasuraman, A. Zeithaml, V.A., \& Berry, L.L. 2003. Delivering Quality Service. Balancing Customer Perceptions and Expectation. New York: The Free Pres. Puspitawati, N.M.D. \& Riana, I.G. 2014. Pengaruh Kepuasan Kerja terhadap Komitmen Organisasional dan Kualitas Layanan. Jurnal Manajemen Strategi Bisnis and Kewirausahaan. Vol. 8, No. 1, pp 68-80.

Ramadhan, N. \& Sembering, J. 2014. Pengaruh Employee Engagement Terhadap Kinerja Karyawan di Human Capital Center PT Telekomunikasi Indonesia, TBK. Jurnal Manajemen Indonesia, Vol. 14, no. 1, pp. 47-58.

Robbins, S. P. 2006. Perilaku Organisasi Edisi Kesepuluh. Jakarta: Indeks Kelompok Gramedia.

Schaufeli, W.B. \& Bakker, A.B. 2003. UWES - Utrecht Work Engagement Scale: Test Manual, Unpublished Manuscript: Department of Psychology, Utrecht University.

Schaufeli, W.B., Bakker A.B., \& Salanova M. 2006. The Measurement of Work Engagement with a Short Questionnaire: A Cross National Study. Educational and Psychological Measurement, Vol. 66, No. 4, pp. 701-716.

Schmidt, F.L., Law, K., Hunter, J.E., Rothsen, H.R., Pearlman, K., \& McDaniel, M. 1993. Refinements in validity generalization methods: implications for the situation specificity hypothesis. Journal of applied Psychology, Vo. 78, pp. 3-12.

Schuler, R.S. \& Jackson, S.E. 1997. Manajemen Sumber Daya Manusia, Edisi Keenam. Jakarta: Erlangga.

Sekaran, U. 2006. Metodologi Penelitian untuk Bisnis. Edisi Keempat. Jakarta: Penerbit Salemba Empat.

Siddhanta, Abhijit \& Roy, D. 2010. Employees Engagement-Engaging the 21th Century Workforce. Asian Journal of Management Research. Online Open Access Publishing Platform for Management Research.

Sopiah. 2008. Perilaku Organisasi. Yogyakarta: ANDI Offset.

Sukotjo, H. 2011. Pengaruh Kepuasan Kerja terhadap Kualitas Pelayanan, Kepuasan Pelanggan, dan Loyalitas Pelanggan pada Perguruan Tinggi Swasta (PTS) di Jawa Timur. Jurnal Aplikasi Manajemen, Vol. 9, No. 2, pp. 650-658. 
Ni Made Dwi Puspitawati, Adhi Krisna Yuliawan / Role of Employee Engagement on Work Satisfaction Regarding Employee Services Quality at the Grand Santhi Hotel Denpasar

Sun, I., Liu, J. \& Farmer, A.K. 2016. Chinese Police Supervisors' Occupational Attitudes: Role Orientation, Community Policing, and Job Satisfaction. An International Journal of Police Strategies and Management, Vol. 39, No. 1.

Suwatno, H \& Priansa, D.J. 2011. Manajemen SDM dalam Organisasi Publik dan Bisnis. Bandung: Alfabeta.

Wibowo. 2012. Manajemen Kinerja Edisi Ketiga. Jakarta: Rajawali Pers.

Widjaja, J. \& Devie. 2014. Pengaruh Job Satisfaction Terhadap Financial Performance Melalui Employee Engagement dan Competitive Advantage Sebagai Intervening Variabel Pada Perusahaan Retail Pabrik di Surabaya. Business Accounting Review, Vol. 2, No. 2, pp. 99-110.

Wirawan. 2009. Evaluasi Kinerja Manajemen Sumber Daya Manusia. Jakarta: Salemba Empat.

Wuryandradi, D. 2014. Pengaruh Kepuasan Kerja, Motivasi, dan Budaya Organisasi terhadap Kualitas Pelayanan PT. Solo Central Taxi Tahun 2011.Jurnal Riset Manajemen, Vol. 1, No. 1, pp. 52-63.

Wyatt, T.A \& Wah, C.Y. 2001. Perception of QWL: A Study of Singaporean Employees Development. Journal Research and Practice in Human Resource Management. Vol.2, No. 2, pp. 59-76.

Umar, H. 2010. Desain Penelitian MSDM dan Perilaku Karyawan. Jakarta: PT Raja Grafindo.

Yee, R.W.Y., Yeung, A.C.L., \& Cheng, T.C.E. 2008. The Impact of Employee Satisfaction on Quality and Profitability in High-Contact Service Industries. Journal of Operations Management, Vol. 25, No. 5, pp. 651-668. 
Review of Management and Entrepreneurship

Volume 02, Number 01, April 2018 